between disturbances of the hair cycle and disturbances of hair pattern.

In conclusion, I am tempted to quote a former President of this College. John Ayrton Paris (1785-1856) wrote in 1822: "For any problem which involves the phenomenon of life is unavoidably embarrassed by circumstances so complicated in their nature, so fluctuating in their operation, as to set at defiance any attempt to appreciate their influence."

\section{Summary}

The differentiation of two aspects of follicular activity is phylogenetically sound and clinically useful. The recurrent cycles of active growth, regression, and rest in the individual hair follicle represent the seasonal moulting cycles of other mammals. The sequence of hair patterns throughout life, which depends on the calibre of the hair produced by each follicle, is linked to the processes of somatic growth, sexual maturation, and ageing.

Disturbances of hair patrern are usually produced by excessive or deficient stimulation of follicles by androgens or by somatotrophin, or by genetically determined defects in follicular response. Most such disturbances are incompletely reversed by removal of the endocrine stimulus.

Disturbances of hair cycles involve modification of the relative duration of the phases of the cycle and are most characteristically determined by excess or deficiency of glucocorticosteroids or thyroid hormones. They are usually completely reversible.

Scientifically planned investigations on hair cycles in man have seldom been undertaken, and conclusions based on comparative studies are tentative.

\section{REFERENCES}

Arnal, M., Dresch, C., and Prader, A. (1961). Helv. paediat. Acta., 16,

Barman, J. M., Pecoraro, V., and Astore, I. (1962). Arch. argent. Derm., Beek, C. (1946). Dermatologica (Basel), 93, 213.

Beek, C. H. (1950). Ibid., 101, 317.
Bullough, W. S., and Laurence, E. B. (1964). Symp. zool. Soc. Lonu., $12,1$.

Cedercreutz, A. (1939). Acta derm.-venereol. (Stockh.), 20, 704.

Chang, H.-C., and Feng, T.-P. (1929). Chin. F. Physiol., 3, 57

Davis, B. K. (1963). Acta endocr. (Kbh.), 44, Suppl. No. 85, p. 9.

Duggins, O. H., and Trotter, M. (1951). Ann. N.Y. Acad. Sci., 53, 569.

Ebling, F. J. (1964). In Progress in the Biological Sciences in Relation to Dermatology, edited by A. Rook and R. H. Champion. Cambridge University Press, London.

_ and Johnson, E. (1964a). Symp. zool. Soc. Lond., 12, 97.

- and Johnson, E. (1964). Endocr., 29, 193 .

Forbes, A. P., Henneman, P, H., Griswold, G. C., and Albright, F. (1954). F. clin. Endocr., 14, 265.

Garn, S. M. (1951). Ann. N.Y. Acad. Sci., 53, 498.

Hamilton, J. B. (1942). Amer. F. Anat., 71, 451

- (1960). F. clin. Endocr., 20, 1309.

and Terada, H. (1963). In The Hirsute Female, edited by R. B. Greenblatt, p. 20. Thomas, Springfield, Ill.

Kligman, A. M. (1961). Arch. Derm., 83, 175.

Le Double, A.-F., and Houssay, F. (1912). Les Vélus. Vigot, Paris.

Le Marquand, H. S., and Bohn, G. L. (1951). Proc. roy. Soc. Med., 44 155 .

Lyell, A., and Whittle, C. H. (1951). Ibid., 44, 576.

Lynfield, Y. L. (1960). f. invest. Derm., 35, 323.

Maguire, H. C. (1964). Lancet, 1, 864.

and Kligman, A. M. (1964). F. invest. Derm., 42, 77.

Mohn, M. P. (1958). In The Biology of Hair, Growth, edited by $W$ Montagna and R. A. Ellis, p. 336. Academic Press, New York.

Montagna, W. (1962). The Structure and Function of Skin, 2nd ed. Academic Press, New York.

Myers, R. J., and Hamilton, J. B. (1951). Ann. N.Y. Acad. Sci., 53, 562. Ormsby, O.'(1930). Arch. Derm., 21, 663.

Ormsby, O. (1930). Arch. Derm., 21, 663. London.

Paris, J. A. (1822). Pharmacologia, 5th ed. London.

Pecoraro, V., Astore, I., Barman, J., and Araujo, C. I. (1964). F. invest. Derm., 42, 427.

Rennels, E. G., and Callahan, W. P. (1959). Anat. Rec., 135, 21.

Reynolds, E. L. (1951). Ann. N.Y. Acad. Sci., 53, 576.

Robinson, R. C. V. (1955). Arch. Derm., 71, 401.

Rook, A. (1965a). In Comparative Physiology and Pathology of Skin, edited by A. Rook and G. Walton. Blackwell, Oxford. (1965b) Geront clin (Basel) In press.

Sainton, P., and Simonnet, H. (1931). Ann. Méd., 29, 263.

Silverman,'S. H., Migeon, C., Rosemberg, E., and Wilkins, L. (1952). Pediatrics, 10 , Mige

Silvestri, U. (1956). G. geront., Suppl. 5, p. 203.

Smith, J. G., Weinstein, G. D., and Burr, J. M. (1959). F. invest. Derm., $32,35$.

Snow, J. S., and Whitehead, R. W. (1935). Endocrinology, 19, 88.

Snyder, L. H., and Yingling, H. C. (1935). Hum. Biol., 7, 608

Straile, W. E., Chase, H. B., and Arsenault, C. (1961). '̧. exp. Zool., 148, 205 .

Summers, V. K. (1949). Acta med. scand., 136, 105.

Szabo, G. (1958). In The Biology of Hair Growth, edited by $\mathbf{W}$. Montagna and R. A. Ellis. Academic Press, N.Y.

Thomas, P. K., and Ferriman, D. G. (1957). Amer. f. phys. Anthrop.,

15, 171.

\title{
Virus Isolations From Throats of Children Admitted to Hospital with Respiratory and Other Diseases, Manchester 1962-4
}

\author{
A. HOLZEL,* M.D., D.C.H. ; L. PARKER, † M.A., B.M., M.C.PATH. ; W. H. PATTERSON, $¥$ M.D., D.C.H. \\ D. CARTMEL, $\S$ M.B., D.C.H. ; L. L. R. WHITE, $\|$ M.D., B.SC., D.C.H. ; ROSEMARY PURDY, A.I.M.L.T. \\ K. M. THOMPSON,g F.I.M.L.T. ; J. O’H. TOBIN, M M.A., B.M., DIP.BACT., M.C.PATH.
}

Brit. med. F., 1965, 1, 614-619

Recently we reported (Holzel et al., 1963) the isolation of 36 strains of respiratory syncytial (R.S.) virus from children with acute respiratory infections admitted to Booth Hall Children's Hospital during January to April 1962. The strains were isolated by the direct inoculation with throat swabs of cell cultures kept in an incubator in the hospital admission-room.

\footnotetext{
* Reader in Child Health, University of Manchester.

t Consultant Bacteriologist. Booth Hall Children's Hospital, Manchester. ¥ Consultant Paediatrıcian, Booth Hall Children’s Hospital, Manchester. Resident Medical Officer, Booth Hall Children's Hospital, Manchester. II Consultant Pathologist, Booth Hall Chıldren's Hospital, Manchester. If From the Public Health Laboratory, Withington Hospital, Manchester.
}

Since then routine throat swabs dealt with in this way have been obtained from the majority of infants and children admitted to the medical wards of this hospital.

Our principal aim in this two-year study from April 1962 to March 1964 was to delineate so far as is possible the role of specific viral agents in the seasonal pattern of respiratory infection in children admitted to hospital.

Children with and without respiratory disease were studied in order to assess the clinical significance of the viruses isolated, as regards both their frequency of occurrence in patients without respiratory symptoms and their association with non-respiratory illness. 


\section{Material and Methods}

From April 1962 two throat swabs were taken from infants and children in the hospital admission-room, one being examined for bacteria and the other for viruses. The swabs for bacteriological examination were placed in Stuart's medium, and the virus swabs, which were inoculated into one rhesusmonkey-kidney and one "Bristol" HeLa-cell culture or another rhesus-monkey-kidnev culture, were treated as described previously until October 1962 (Holzel et al., 1963). From then onwards the virus swabs were inoculated into one monkey-kidney and one HeLa-cell culture, embryo calf serum being substituted for rabbit serum in the maintenance media used for the later cultures (Report, 1964).

\section{Results}

\section{Incidence of Virus Isolation from Cases of Respiratory Diseases}

During the eight trimesters of the study 1,219 cases of respiratory infection were swabbed and 396 viruses isolated (Table I). The virus encountered most frequently was R.S. virus ( 215 strains), followed by the parainfluenza viruses (66 strains), adenoviruses (49 strains), and picornaviruses (30 strains). The age groups and broad clinical syndromes of the patients in whom these viruses were found are given in Table II.

Respiratory syncytial virus was isolated during each month from December 1962 onwards, epidemics occurring in the first and last trimesters of 1963. During these epidemics it was the most common agent encountered, being found in $51 \%$ and $56 \%$, respectively, of infants admitted with disease of the lower respiratory tract.
Strains of parainfluenza virus type 1 were found during a limited period, from August 1962 until March, 1963, with a peak in December, whereas the type 3 strains occurred throughout the period of study; the only type 2 strains encountered were found in January and February 1963.

The adenoviruses were isolated throughout the period of study, with an increased incidence at the end of the winters and in the spring.

Except for one rhinovirus, all picornaviruses found belonged to the enterovirus group, the majority being Coxsackie $\mathbf{B}$ viruses. They were recovered chiefly during the summer and autumn months.

Seven strains of influenza $A_{2}$ virus were found during March and April 1963, and four unidentified haemadsorption agents during February and March 1964 . The influenza strains were found in monkey-kidney-cell cultures and only with difficulty were they adapted to growth in eggs. Influenza $A_{2}$ strains isolated in 1964 during the trimester following the period covered by this paper also failed to adapt readily to eggs. During March and April 1963 six other monkey-kidney-cell cultures inoculated with throat swabs from patients showed haemadsorption, but no virus could be isolated on passage in spite of dilution of culture fluids, passage of cells, and egg inoculation. It was possible that failure to detect virus in these six instances was due to discarding the cultures too soon, since the appearance of haemadsorption on passage of some of these $A_{2}$ strains was delayed as long as 14 days.

Fifteen strains of herpes simplex were isolated, only one of which was found associated with another virus. The three strains isolated from infants were probably causing primary infections, and may have played a significant part in their respiratory disease.

TABLE I.-Isolations of Viruses from Throat Swabs from Children with Respiratory Infections, April 1962 to March 1964

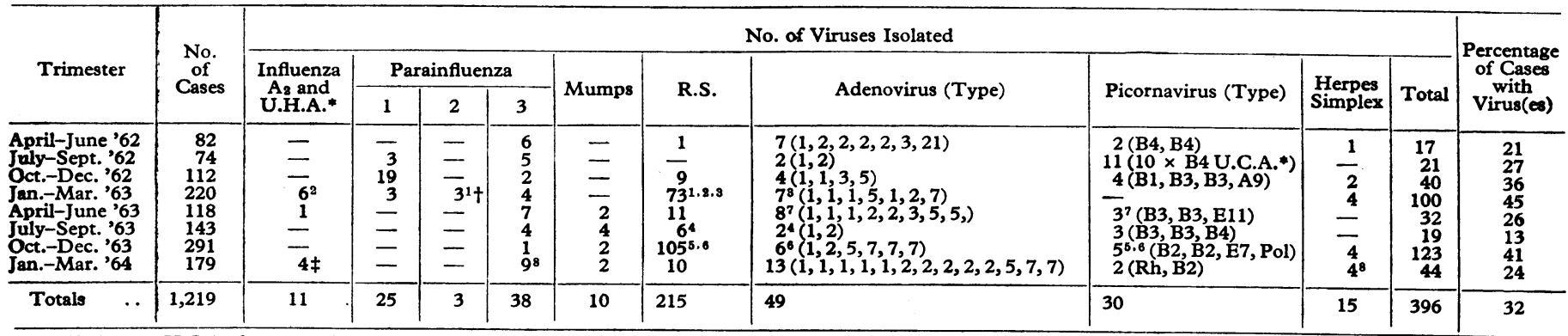

- U.H.A. or U.C.A. denotes unidentified haemadsorption or cytopathic agent. For other codes see Table III.

$+1-8$ refers to case with isolation
$\neq$ Denotes case with U.H.A.

TABLE II.-Relation Between Respiratory Disease Syndrome, Age, and Virus Isolated, April 1962 to March 1964

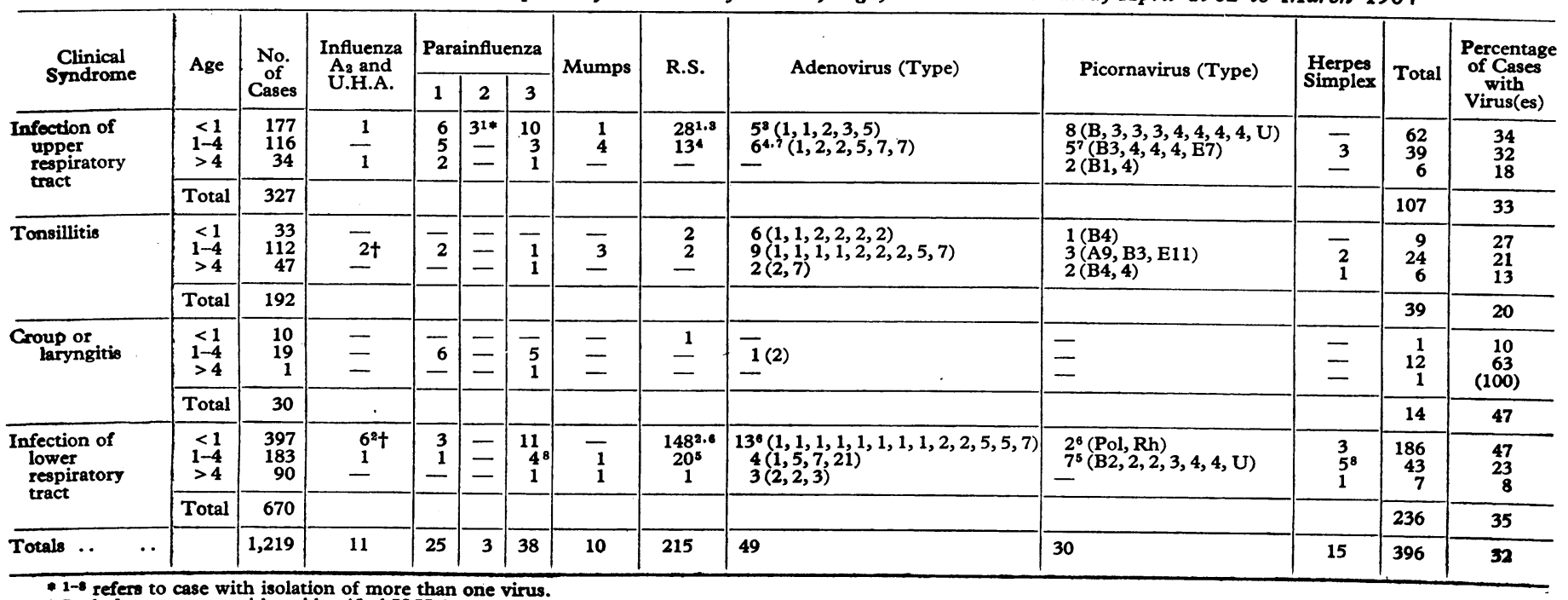




\section{Virus Isolations from Cases of Non-respiratory Disease}

Throat swabs were taken from 1,333 patients with nonrespiratory disease and yielded 87 viruses. Herpes simplex was the commonest, 23 of the 35 strains found being from children with stomatitis. The number of cases and the viruses isolated in each trimester are given in Table III, where the conditions for which the children were admitted have been arbitrarily subdivided into broad clinical groups. The gastroenteritis (G.E.) group comprised all cases whose predominant system was diarrhoea, while other gastro-intestinal (G.I.) syndromes included "failure t thrive," pyloric stenosis, etc. Diseases of the central nervous system (C.N.S.) included meningitis, febrile convulsions, epilepsy, congenital cerebrospinal defects, mental retardation, etc. The pyrexia-ofunknown-origin (P.U.O.) group was limited to cases with fever alone, and the miscellaneous group included such diseases as rheumatic fever, nephritis, myalgia, the blood dyscrasias, mumps, eczema, etc.

The three isolations of R.S. virus in the "non-respiratory" group were from a child with pyrexia, a baby with meningococcal meningitis, and a baby with gastro-enteritis who had been discharged a few days carlier from another hospital after recovering from bronchopneumonia.

Two babies included in the gastro-enteritis group, and from whom parainfluenza viruses were recovered, had concurrent mild upper respiratory infection, one also having an E.C.H.O. virus type 14 in her faeces. Two other parainfluenza viruses were found in babies with vomiting of undetermined aetiology, and a third was associated with an adenovirus type 1 in a baby who was failing to thrive. The remaining parainfluenza viruses were found in an infant with thrombocytopenic purpura and a baby admitted because of a heart malformation.

Adenoviruses were isolated from six cases of alimentarytract disease, three children with convulsions, three with unexplained fever, a child with cervical adenitis, one with rheumatic fever, and another with eczema.

Of the picornaviruses the Coxsackie viruses were found mainly in cases of myalgia, aseptic meningitis, fever, and mesenteric adenitis. However, the two " $M$ " strains of rhinovirus encountered were isolated from babies with meningoencephalitis, one of whom died (Holzel et al., 1965).

\section{Sensitivity of Rhesus-monkey-kidney and HeLa-cell Cultures to Respiratory Viruses}

A comparison of isolations of viruses from throat swabs in rhesus-monkey-kidney and HeLa-cell cultures is given in Table IV in those cases where this comparison was possible. In these instances monkey-kidney-cell cultures were subcultured to HeLa cells, whether any cytopathic effect was noted or not, if a virus was found in the corresponding HeLa-cell cultures. All HeLacell cultures were tested by the haemadsorption technique, using guinea-pig cells, before being discarded. All monkey-kidneycell cultures from babies less than 1 year of age with lower respiratory infections were also cultured to HeLa cells, irrespective of the findings in the latter cultures.

TABLE IV.-Comparison of Isolations of Viruses from Throat Swabs in Rhesus-monkey-kidney and HeLa-cell Cultures

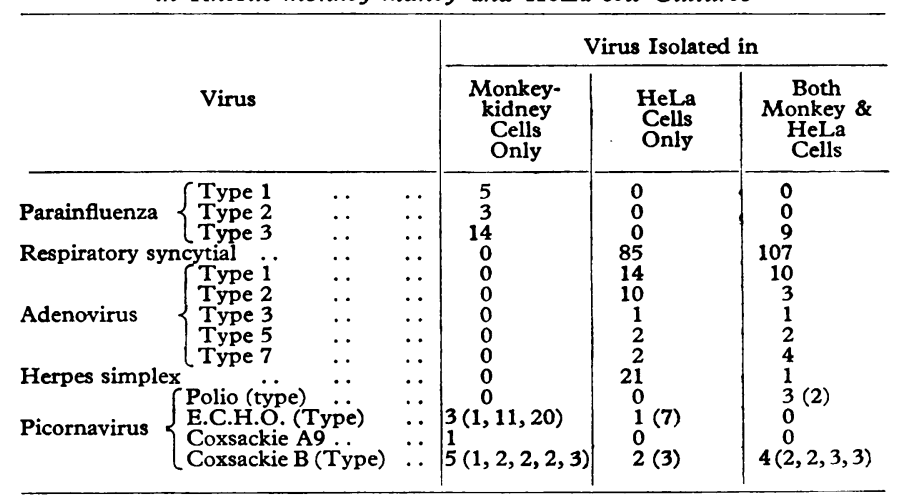

\section{Bacteriological Findings}

During the winter of 1963 members of the haemophilus group of organisms were isolated from a greater proportion of R.S.virus infections than from other respiratory infections. This is in agreement with our previous results (Holzel et al., 1963). No significant association of bacteria with the other virus infections was apparent. (Hulley and Parker, to be published.)

Although group A streptococci were isolated from a higher, and viruses from a lower, percentage of children with tonsillitis than from other respiratory groups (Table V), the incidence $(11 \%)$ of these bacteria was far lower than might have been anticipated in this clinical condition. This was partly explained by including in the "tonsillitis" group cases with reddening and swelling of the tonsils and slight enlargement of the regional lymph nodes but with no obvious exudate. Another possible contributory factor was the large number of young children in our material. Of the children with respiratory infections, $50.6 \%$ were less than 1 year old, and only $14.1 \%$ were more than 4 years old. The results obtained by Clarke et al. (1964) suggest that they too found streptococci of groups A and $G$ less frequently in the younger age-groups.

TABLE V.-Isolation of $\beta$-haemolytic Streptococci in Relation to Clinical Syndromes (Throat Swabs, April 1962-March 1964)

\begin{tabular}{|c|c|c|c|c|}
\hline \multirow{2}{*}{ Syndrome } & & \multirow{2}{*}{$\begin{array}{l}\text { Total No. } \\
\text { of Cases }\end{array}$} & \multicolumn{2}{|c|}{$\begin{array}{c}\text { Percentage of Cases from } \\
\text { which Streptococci were } \\
\text { Isolated }\end{array}$} \\
\hline & & & Group A & $\begin{array}{c}\text { Groups } \\
A, C \text {, and } G\end{array}$ \\
\hline $\begin{array}{l}\text { Upper respiratory tract infection } \\
\text { Tonsillitis } \\
\text { Croup } \\
\text { Lower respiratory tract infection } \\
\text { Non-respiratory diseases }\end{array}$ & $\begin{array}{l}\cdots \\
\cdots \\
\cdots\end{array}$ & $\begin{array}{r}327 \\
192 \\
30 \\
670 \\
1,333\end{array}$ & $\begin{array}{r}5 \cdot 8(19) \\
10.9(21) \\
6 \cdot 7(2) \\
4.9(33) \\
4.3(57)\end{array}$ & $\begin{aligned} & 8 \cdot 0(26) \\
& 15 \cdot 1(29) \\
& 13 \cdot 3(4) \\
& 7 \cdot 5(50) \\
& 7 \cdot 7(101)\end{aligned}$ \\
\hline
\end{tabular}

Figures in parentheses show the number of cases from which the streptococc were isolated.

TABLE III.-Virus Isolations from Throat Swabs of Children with Non-respiratory Disease, April 1962 to March 1964

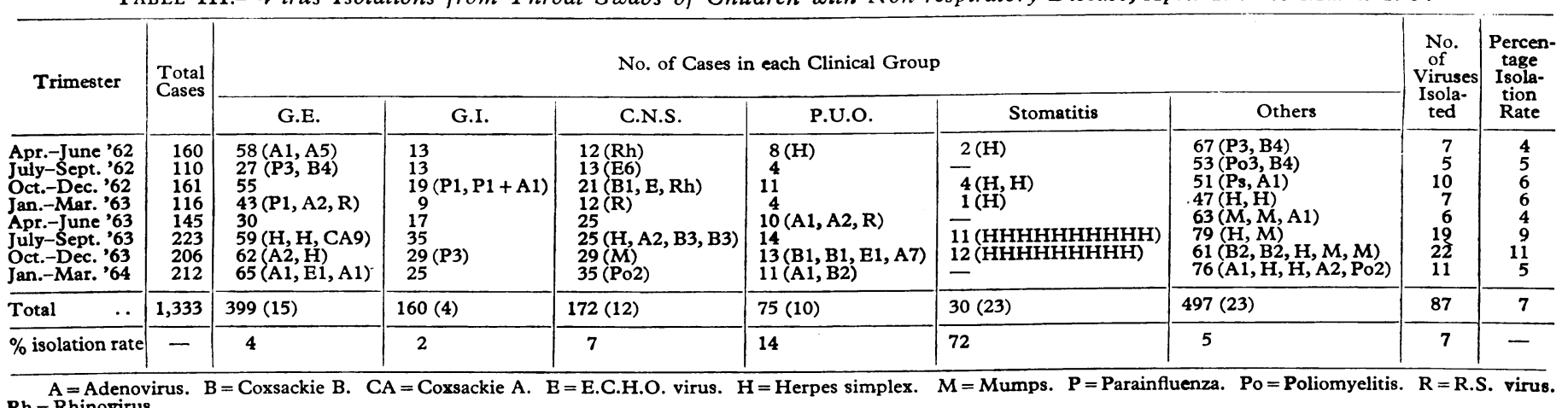




\section{Necropsy Studies}

Two patients yielding R.S. virus died and were examined post mortem.

\section{Case A}

A male infant of 4 months was admitted to hospital on 8 November 1963 with "chestiness" and difficulty in breathing of 24 hours' duration. He had an expiratory wheeze, developed progressive dyspnoea with numerous fine rales over the lung fields, and died two and a half days after admission.

Necropsy showed him to have been a well-nourished child with some cyanosis. The upper respiratory tract appeared normal, but the trachea and bronchi were congested and contained some mucoid secretion. The pleural sacs were normal. The lungs were well expanded and tended to remain so after the pleurae were opened they weighed $120 \mathrm{~g}$. compared with an expected weight of $70 \mathrm{~g}$.

No consolidation was apparent, but slight collapse posteriorly and emphysema with moderate congestion anteriorly were seen. The other organs were congested but otherwise unremarkable apart from some fatty-liver change.

Histological examination of the lungs showed severe lesions of the bronchial tree, which were widespread but did not as a rule affect the terminal bronchiolar segments. The most frequently observed changes were desquamation and degeneration of the bronchial epithelium, accompanied by an infiltration of leucocytes (principally lymphocytes, with some monocytes and occasional neutrophil polymorphs) which commonly formed a dense mantle around the bronchus (Fig. 1). Small cytoplasmic inclusions were detected in some bronchial epithelial cells. These eosinophilic inclu-

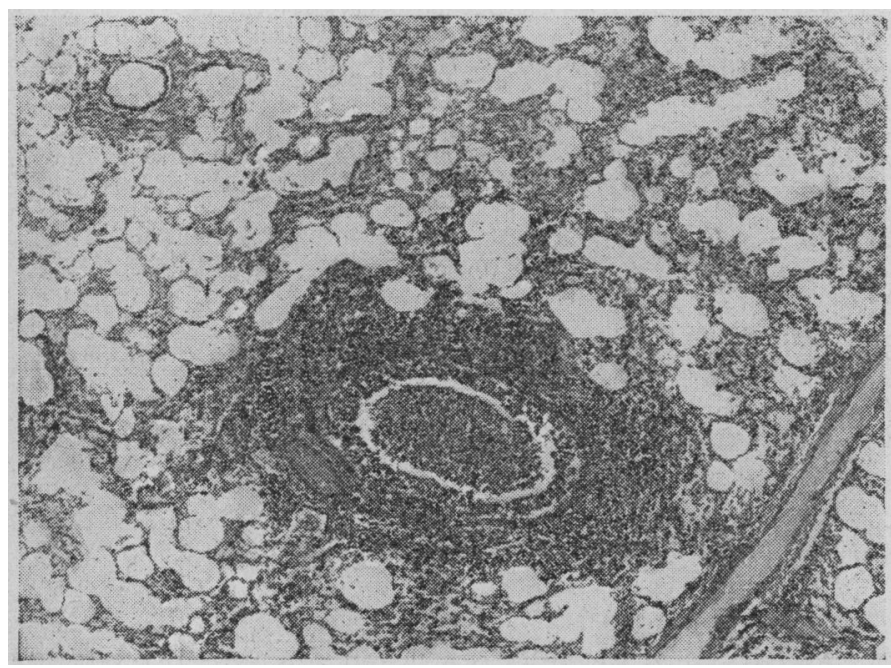

Fig. 1.-Case A. Affected bronchus and surrounding lung.

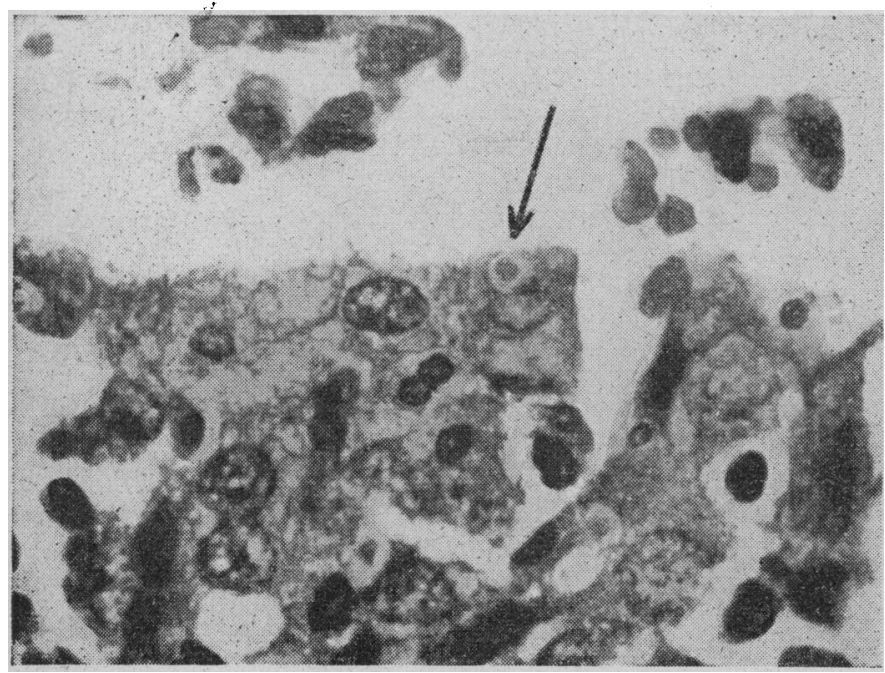

Fig. 2.-Case A. Cytoplasmic inclusion in bronchial epithelium. sions were enclosed within a vacuole, usually occurred singly, and were often situated close to the nucleus (Fig. 2). Some bronchi showed little more than ballooning of the goblet cells, leading to a variable degree of desquamation of both these and the intervening ciliated columnar cells. Others showed obvious inflammatory changes with superficial desquamation accompanied by proliferative changes in the deeper layers of the epithelium. Apart from the bronchial changes the lungs showed only trivial microscopical lesions. There was a little collapse and compensatory emphysem with congestion, mild focal oedema, and slight proliferation of alveolar phagocytes. Where there was heavy mural infiltration of affected bronchi the cellular infiltrate extended into the adjacent lung, but there was no frank consolidation.

\section{Case B}

A female infant 2 months old was admitted to hospital on 10 November 1962 for investigation of occasional episodes of vomiting. There were no abnormal findings on examination. During the following afternoon the child was found dead in her cot. She had not vomited while in hospital, and her condition had not given cause for concern. Necropsy revealed nothing abnormal externally apart from cyanosis of the lips. The trachea and main bronchi contained some frothy and slightly blood-stained oedema fluid. The pleural sacs were normal. Although much of the lung parenchyma was well aerated, there was mottled congestion and some oedema. Petechial haemorrhages were present beneath the visceral pleura and in the thymus. The liver was pale, but other organs appeared normal.

Microscopically the principal changes were in the lung parenchyma. (Fig. 3). There was widespread congestion and oedema, the latter being most severe in the central portions of the lobes and accompanied by some diapedesis of red cells. Monocytoid leucocytes were present in many alveolar walls and within some alveoli, accompanied in the latter by a variable number of large phagocytes with eosinophilic cytoplasm. Lesions of the bronchial tree were minimal and sparse, consisting of ballooning of goblet cells, some epithelial desquamation, and occasional focal mural infiltration with lymphoid cells. A few doubtful eosinophilic. inclusions were seen in the bronchial epithelium.

\section{Discussion}

In the course of this two-year study the incidence and type of viruses found in children admitted to Booth Hall Hospital with acute respiratory disease were compared with those in patients with non-respiratory illnesses. Viruses were isolated from $32 \%$ of the respiratory cases and from $7 \%$ of the others ; a quarter of the viruses found in the latter group were strains of herpes simplex virus isolated from cases of stomatitis. Influenza and R.S. viruses, apart from three doubtful exceptions, occurred only in association with obvious respiratory infections, while the parainfluenza viruses were found ten times as often

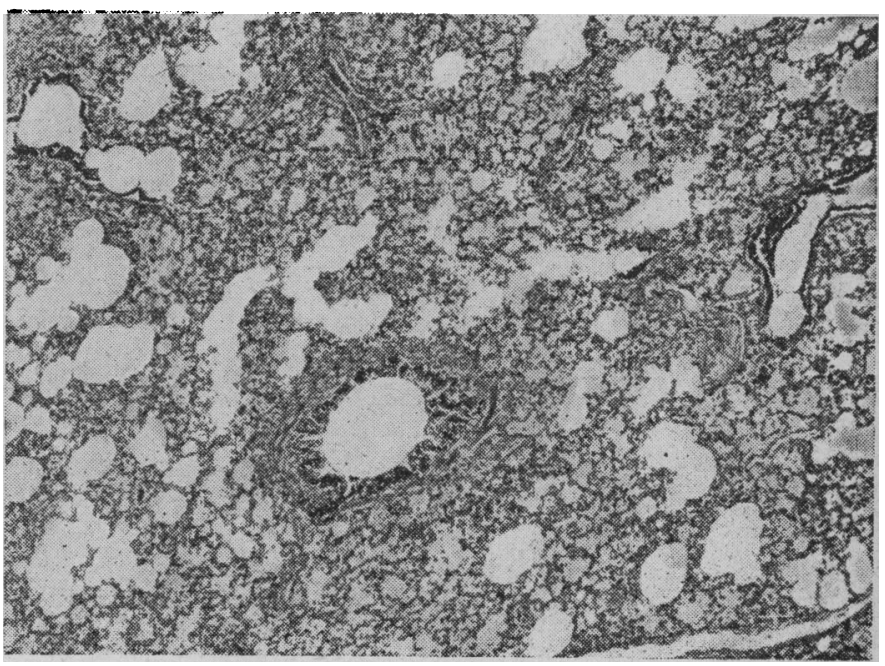

FIg. 3.-Case B. Lung changes. 
in cases with respiratory disease as in those without. Although the adenoviruses and the Coxsackie viruses were found mainly in cases with respiratory disease, they were also present in other clinical syndromes such as Bornholm disease, aseptic meningitis, and mesenteric adenitis, which are accepted manifestations of one or both of these virus infections.

In the six broad groups of non-respiratory disease, other than stomatitis, no one single virus appeared with any frequency. The low incidence of respiratory viruses in the gastro-enteritis group, which consisted mostly of infants, would suggest that these play little part in this syndrome.

R.S. virus was the one most frequently encountered in this investigation and was also the most important clinically, as it produced yearly epidemics of disease of the lower respiratory tract, particularly in infants. During the first and last quarters of 1963 it was isolated from over half the infants admitted with such infections. Recent experience suggested that even this high incidence may represent only 75 to $80 \%$ of infections with this virus.

This virus can cause infections of the respiratory tract in the newborn period as well as in infancy, $15 \%$ of our patients being less than 1 month of age.

Involvement of the lower respiratory tract by R.S. virus gave a characteristic clinical picture which during epidemics allowed a presumptive aetiological diagnosis merely on the basis of physicial examination. But when the infection was limited to the upper respiratory tract the illness was not distinctive. The most common patterns of disease in infants in our experience and that of others (Adams et al., 1961 ; Hilleman, 1963) were bronchitis, bronchiolitis, and bronchopneumonia. A constant symptom was a hacking cough with paroxysms that increased in length and frequency and were accompanied by vomiting, thus interfering with feeding and sleep and leading rapidly to exhaustion. Particularly in the sporadic cases the paroxysmal cough simulated either pertussis before whooping developed or the first pulmonary manifestation of fibrocystic disease of the pancreas. Three of six cases in which an initial diagnosis of pertussis was not substantiated by subsequent progress or by laboratory investigations harboured R.S. virus.

The differentiation of infantile asthma from R.S.-virus bronchitis needed care, since the latter was associated with wheezing, rhonchi, and indrawing of the intercostal spaces, thus manifesting a syndrome of more or less severe expiratory dyspnoea. The presence of the latter in bronchiolitis, accompanied by paroxysmal cough and showers of fine rales in both lungs, made it into a distinctive entity which could be recognized clinically with experience. An attempt to make an aetiological diagnosis at the time of admission proved successful, R.S.-virus infection being correctly diagnosed in over $90 \%$ of cases of bronchiolitis. We differ here from Parrott et al. (1963), who assert that "in spite of the frequency and importance of the acute infections there have been few clinical features ... that might enable the clinician predictably to estimate which agent is responsible."

The pathological features in one (Case A) of the two fatal cases included bronchial lesions resembling those described by Adams (1941) under the title of "Primary Virus Pneumonitis with Cytoplasmic Inclusion Bodies." In subsequent papers Adams et al. (1961) provided evidence that the condition was associated with respiratory syncytial virus. Some of the lesions were also comparable with those described by us accurring in another child dying with R.S.-virus infection (Holzel et al., 1963), although in that instance no inclusions were identified.

The post-mortem findings in Case $\mathrm{B}$, however, showed striking differences. The major changes were found in the lung parenchyma, and bronchial lesions were comparatively trivial. The features described were such as are often seen in "cot deaths." Whether the recovery of R.S. virus was fortuitous or significantly related to the pulmonary lesions must for the present remain in some doubt, but it is hoped that future studies with fluorescent antibody may give further evidence by demonstrating the presence of virus in the lesions.

The parainfluenza viruses were the predominant agents isolated from the children with croup, six of them being type 1 and six type 3 . In one patient laryngitis without significant obstruction was due to an infection with R.S. virus, and from another an adenovirus type 2 was isolated. Although the incidence of croup varied with the prevalence of the parainfluenza viruses, the commonest respiratory manifestation of this viral infection was simple involvement of the upper respiratory tract with or without coryza. Type 3 parainfluenza virus was more likely to produce bronchitis or bronchopneumonia than type 1 , the subjects being mainly infants or young children, a feature already noted by Chanock et al. (1963).

Mumps virus was isolated from 10 patients with respiratory disease without involvement of the salivary glands, one of whom had pneumonia. This patient also had a concurrent Coxsackie A9 infection.

In more than one-third of the patients from whom adenovirus was isolated a clinical diagnosis of pneumonia was made, but no features were observed which might distinguish this virus pneumonia from many of the others occurring in childhood. The bronchial obstruction seen in R.S.-virus infection was not evident. Most of the children with disease of the lower respiratory tract were under 4 years of age, a feature of adenovirus infection already observed by others (Chany et al., 1958 ; Van der Veen, 1963). The adenovirus tonsillitis observed was of the exudative type in some of our patients, but usually there was only reddening and swelling of the tonsils with some enlargement of the regional lymph nodes. No particular type of adenovirus was associated with any of the clinical syndromes.

The enteroviruses produced mostly upper respiratory infection, usually pharyngitis or tonsillitis. Pyrexia was present in all these cases and varied from 37.5 to $40^{\circ} \mathrm{C}$.: it was often intermittent and lasted from one to five days. Ten children in whom Coxsackie virus types B3 or B4 were found had definite bronchitis, and one had clinical and radiological evidence of pneumonia. It is possible that involvement of the lower respiratory tract with these viruses is more common in this country than in the United States (Johnson et al., 1963 ; Dr. J. H. Connolly, personal communication) and that they can occasionally even cause a fatal pneumonia (Dr. T. H. Flewett, personal communication). In younger children vomiting was not infrequent, and when accompanied by abdominal pain led to their being sent to hospital as cases of appendicitis, but on admission they were usually found to have respiratory symptoms only. In Manchester, as in Belfast (Dr. Connolly, personal communication), respiratory disease was the commonest manifestation of Coxsackie virus infections in children admitted to hospital.

Forty-three cases of otitis media were included in the group of patients with infections of the upper respiratory tract, but only five viruses were isolated from them. These were an R.S. virus, a Coxsackie B4, a mumps, a parainfluenza type 3, and an adenovirus type 7. An R.S. virus was found in one of three cases of tonsillitis with concurrent otitis, and one rhinovirus from eight cases of otitis media associated with lower respiratory infections.

\section{Conclusions}

Within the limits of the laboratory methods applied, some of the viruses significantly related to respiratory disease in Manchester children have been determined, and although the study was carried out on patients requiring admission to hospital it is possible that it reflects in some measure the pattern of viral infections in the child population at large.

In Manchester and neighbouring towns (Report, 1964) R.S. virus was of particular importance in childhood and especially during infancy, as it was the chief cause of the annual epidemics 
of acute bronchiolitis which were a source of concern to the family doctor and the paediatrician alike. In Britain the frequency of severe infections produced by this virus may be greater in the industrial towns such as Newcastle (Andrew and Gardner, 1963), Sunderland (Crone et al., 1964), Birmingham (Sandiford and Spencer, 1962), Bristol (Clarke et al., 1964), and Glasgow (Ross et al., 1964) than in country towns such as Cirencester (Higgins et al., 1963, 1964).

The occurrence of the other virus infections may also vary in different parts of the country from year to year. In the latter part of 1962 parainfluenza type 1 was frequent in the North-west and in Cambridge (Banatvala et al., 1964), but not in Cirencester, where type 2 was the commonest virus isolated during this period. But an accurate analysis of the relative importance of these agents in different parts of the country cannot be determined until standard methods of virus isolation are used, as isolation rates are difficult to interpret owing to the variety of techniques employed.

Respiratory viruses were rarely isolated in the absence of respiratory symptoms or from healthy people. Although the types of upper respiratory infection caused by the different viruses could not be readily distinguished, some agents were associated with definite clinical syndromes. R.S. virus was the main agent of bronchiolitis, the parainfluenza viruses of croup, and the adenoviruses of non-bacterial tonsillitis.

Although R.S. virus appears to encourage the proliferation of haemophilic bacteria in the respiratory tract, the interplay between viruses and bacteria in producing the clinical syndromes was far from clear, but it would appear that in infants and young children viruses can often produce severe clinical disease, and perhaps death, without involvement by larger micro-organisms.

\section{Summary}

During a two-year period from April 1962 to March 1964 396 viruses were found in the throats of 1,219 children with respiratory disease, and 87 viruses in the throats of 1,333 children with other diseases, admitted to Booth Hall Children's Hospital. Viruses were isolated from throat swabs by the direct inoculation of cell cultures kept in an incubator in the admission-room. Respiratory syncytial virus and influenza and parainfluenza viruses were rarely found in cases of nonrespiratory disease, while the majority of adenoviruses and picornaviruses isolated were also associated with respiratory diseases. Respiratory syncytial virus was isolated most often, being the cause of the large annual epidemics of bronchiolitis in infants in the Manchester area. This virus was the only one isolated which appeared to alter the respiratory bacterial flora appreciably. The necropsy findings in two fatal cases associated with this virus infection are also described.

We are grateful to Dr. F. T. Perkins, of the Medical Research Council Laboratories, London, for the generous supply of monkeykidney cells, without which this work could not have been carried out ; to Dr. M. S. Pereira, of the Virus Reference Laboratory, Central Public Health Laboratory, London, for confirming our isolations of influenza virus and some of the other agents isolated; and to the resident medical staff for taking the routine throat swabs.

\section{REPERENCES}

Adams, J. M. (1941). F. Amer. med. Ass., 116, 925.

- Imagawa, D. T., and Zike, K. (1961). F.-Lancet, 81, 502 ; f. Amer. med. Ass., 176, 1037 .

Andrew, J. D., and Gardner, P. S. (1963). Brit. med. 7., 2, 1447.

Banatvala, J. E., Anderson, T. B., and Reiss, B. B. (1964). Ibid., 1, 537. Chanock, R. M., Parrott, R. H., Johnson, K. M., Kapikian, A. Z., and Bell, J. A. (1963). Amer. Rev. resp. Dis., 88 (Part 2), 152.

Chany, C.., Lépine, $P_{\dot{y}}$, Lelong, M., Le Tan Vinh, Satgé, P., and Virat, J.

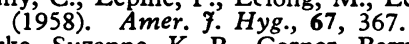

Clarke, Suzanne, K. R., Corner, Beryl D., Gambier, D. M., Macrae, J., and Peacock, D. B. (1964). Brit. med. Ұ., 1, 1536.

Crone, P. B., Heycock, J. B., Noble, T. C., and Patton, J. B. (1964).

Ibid., 1,'1539. Minist. Hlih Lab. Serv., 23, 93.

Ellis, E. M., and Boston, D. G. (1963). Ibid., 22, 71.

Hilleman, M. R. (1963). Amer. Rev. resp. Dis., 88 (Part 2), 181.

Holzel, A., Parker, L., Patterson, W. H., White, L. L. R., Thompson, K. M., and Tobin, J. O'H. (1963). Lancet, $1,295$.

- Smith, Patricia A., and Tobin, J. O'H. (1965). Acta paediat. In press.

Johnson, K. M., Bloom, H. H., Forsyth, B., Mufson, M. A., Webb, P. A., and Chanock, R. M. (1963). Amer. Rev. resp. Dis., 88 (Part 2), 240.

Parrott, R. H., Vargosko, A. J., Hyun, W. K., and Chanock, R. M. (1963). Ibid., 88, (Part 2), 73 .

Report (1964). Mth. Bull. Minist. Hlth Lab. Serv., 23, 136.

Ross, Constance, A. C., Stott, E. J., McMichael, S., and Crowther, I. A. (1964). Arch. ges. virusforsch., 14, 553 .

Sandiford, B: R., and Spencer, B. (1962). Brit. med. 7., 2, 881.

Van der Veen, J.' (1963). Amer. Rev. resp. Dis., 88 (Part 2), 167.

\title{
Cardiovascular, Metabolic, and Thermoregulatory Disturbances in Patients with Erythrodermic Skin Diseases
}

\author{
R. H. FOX,* M.B., PH.D. ; SAM SHUSTER, † M.B., PH.D., M.R.C.P.; ROGER WILLIAMS, $\ddagger$ M.D., M.R.C.P. ; \\ JANET MARKS, $\dagger$ B.M., M.R.C.P. ; R. GOLDSMITH,* M.B. ; R. E. CONDON, $\ddagger$ M.D.
}

Brit. med. F., 1965, 1, 619-622

Patients with generalized psoriasis, exfoliative dermatitis, and other widespread erythrodermic skin diseases often exhibit clinical signs of increased peripheral blood-flow, and Shuster (1963) drew attention to cardiac failure in such patients. Excessive heat loss from erythrodermic skin might be anticipated and hypothermia has been reported (Krook, 1960 ; Magnusson, 1960). It was felt that the nature of these serious complications merited further investigation, and this report presents measurements of cardiac output, peripheral blood-flow, basal metabolic rate, thyroid function, and pressor amine

\footnotetext{
* Division of Human Physiology, Medical Research Council Laboratories, Hampstead, London.

$\dagger$ Denarment of Dermatology, University of Newcastle upon Tyne.
$\ddagger$ Royal Free Hospital, London.
}

excretion in patients with widespread erythrodermic skin conditions.

\section{Patients and Methods}

All 11 patients had been admitted to hospital with exfoliative dermatitis or generalized psoriasis (see Table III). The haemodynamic and thermoregulatory disturbances were studied in six patients; in three of these and in a further five patients the mechanism of the raised B.M.R. was investigated in greater detail.

Cardiac Output, Venous Pressure, and Plasma Volume.The cardiac output was measured in the basal fasting state by a dye-dilution technique using an ear oximeter and a 